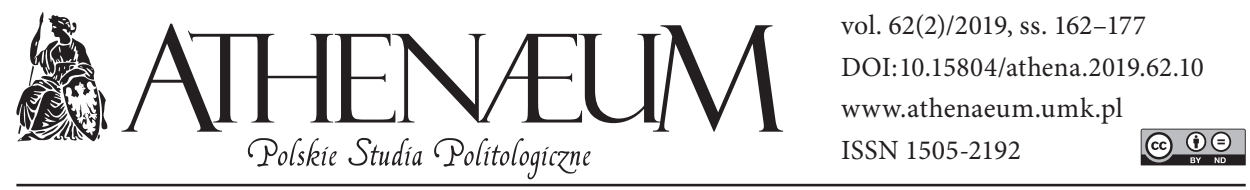

\title{
WŁADZA POLITYCZNA W NAUCZANIU PAPIEŻA BENEDYKTA XVI
}

\author{
POLITICAL POWER IN THE POPE BENEDICT XVI'S TEACHING
}

\author{
Paweł Kusiak* 주
}

\begin{abstract}
ABSTRAKT
Przedmiot niniejszego artykułu stanowi nauczanie społeczne Kościoła katolickiego ze szczególnym uwzględnieniem interpretacji i wkładu weń papieża Benedykta XVI. Autor pragnie dokonać rekonstrukcji stanowiska papieża Benedykta odnośnie władzy politycznej. $\mathrm{W}$ ramach artykułu autor analizuje sposób, $\mathrm{w}$ jaki zjawisko władzy politycznej interpretowane jest w katolickiej nauce społecznej oraz sposób, w jaki papież Benedykt XVI interpretował i rozwijał nauczanie Kościoła dotyczące tej problematyki. Dodatkowo rozbudowany został fragment dotyczący stosunku Benedykta XVI do systemu politycznego demokracji.
\end{abstract}

Słowa kluczowe: Benedykt XVI; katolicka nauka społeczna; katolicka doktryna społeczna; polityka; władza
The subject of this article is catholic social teaching including its interpretation and contribution of Pope Benedict XVI. Author tries to reconstruct the point of view of Benedict XVI about political power. In the article, the author analyzes how catholic social teaching interprets political power problem as well as the problem of how Benedict XVI's interpretation and developing of catholic social teaching refer to the issue of political power. Additionally, the author analyzes the problem of attitude of Benedict XVI to political system of democracy.

Keywords: Benedict XVI; catholic social teaching; catholic social doctrine; politics; power

* Akademia Marynarki Wojennej, Wydział Nauk Humanistycznych i Społecznych. 


\section{UWAGI WSTĘPNE}

Celem niniejszego artykułu jest rekonstrukcja nauczania papieża Benedykta XVI odnoszącego się do władzy politycznej. Główny problem badawczy wyrazić można w formie następującego pytania: „Czy Papież Benedykt XVI wniósł do katolickiej nauki społecznej (dalej KNS) nowe charakterystyczne i nieobecne wcześniej elementy związane z rozumieniem władzy politycznej?”. Odpowiedzi na te pytanie autor poszukuje w oparciu o metodę analizy źródeł, którymi są pisma papieża Benedykta XVI (Encykliki, Adhortacje apostolskie, Listy apostolskie, Orędzia) oraz nauczanie papieskie publikowane m.in. na łamach wydania polskiego L'Osservatore Romano'. Autor stawia tezę, że następca Jana Pawła II był twórczym kontynuatorem ukształtowanego po II wojnie światowej nurtu KNS, który afirmował system liberalnej demokracji.

Mówiąc o zakorzenieniu nauczania Benedykta XVI w tradycji KNS, konieczne jest przypomnienie jej definicji, genezy oraz głównych założeń. KNS sama siebie definiuje jako pogłębioną refleksję nad egzystencją człowieka w społeczeństwie w kontekście międzynarodowym, która rozwijana jest w świetle wiary i tradycji Kościoła. Swój podstawowy cel widzi w wyjaśnieniu rzeczywistości w kontekście ewangelicznej nauki o człowieku, jego powołaniu doczesnym oraz transcendentnym (Kompendium Nauki Społecznej Kościoła, 2005, s. 102). Twórcy KNS dystansują się jednak od określania jej jako programu politycznego. Vittorio Possenti podkreśla, że KNS nie proponuje żadnego konkretnego modelu ani zbioru zasad, które mogą stanowić potencjalną alternatywę dla reguł liberalnych, marksistowskich, kontraktualistycznych i neokontraktualistycznych (Possenti, 2000, s. 33). Zauważyć również należy, że KNS nie powinno się rozpatrywać jako standardowej dyscypliny naukowej, a jako interakcję podmiotów. Pierwszym z nich jest społeczność religijna, którą rozmieć należy jako zbiorowość ludzi w rożnym stopniu identyfikujących się z religią katolicką. Kolejnym jest autorytet normatywny społeczności religijnej, czyli magisterium Kościoła. W Kościele

1 Autor starał się bazować przede wszystkim na materiałach, w których Benedykt XVI wypowiada się z perspektywy Nauczycielskiego Urzędu. Od tej reguły nastąpiły jednak wyjątki. Najważniejszym z nich jest wydana w 2004 (w Polsce w 2005) roku książka kard. J. Ratzingera (2004). Autor zdecydował się włączyć ją do bibliografii niniejszego artykułu, gdyż tezy w niej prezentowane w dużym stopniu uzupełniają wiele kwestii, które Benedykt XVI jako papież poruszał w swym nauczaniu. Warto podkreślić, że sam Papież zwracał szczególną uwagę na to, aby nie było wątpliwości, które z jego wypowiedzi mają status Nauczycielskiego Urzędu, a które są wynikiem jego osobistej refleksji (J. Ratzinger/Benedykt XVI, 2011, s. 15). 
katolickim jest to władza autorytatywnego określania prawdy, sprawuje ją papież wraz z biskupami. Ostatnim podmiotem KSN są analitycy i specjaliści zajmujący się interpretacją założeń doktrynalnych (Góra-Szopiński, 2010, s. 52). W związku z tym KNS traktować należy w dużym stopniu jako dyscyplinę normatywną, czyli zajmującą się opracowaniem postulatów dotyczących tego, jak rzeczywistość powinna wyglądać, a nie jaka jest empirycznie. Można również zgodzić się z Józefem Kellerem (1989, s. 14), który w wydanej w 1989 r. pracy stwierdza, że KNS jest w gruncie rzeczy tym samym co katolicka etyka społeczna, ale dostosowana do nowych sytuacji i problemów związanych z działalnością Kościoła w świecie. Podkreślić także należy, że w toku swego ponad stuletniego rozwoju KNS wykrystalizowała trzy uniwersalne zasady, na podstawie których rozwija ona swe twierdzenia. Pierwszą z nich jest antropocentryzm, który w ujęciu katolickim jest ściśle związany z personalizmem i humanizmem chrześcijańskim. Uznaje on osobę ludzką za byt najwyższy, jedyny i niepowtarzalny. $Z$ antropocentryzmu chrześcijańskiego wynika zasada pomocniczości (subsydiarności). Stanowi ona jego doprecyzowanie w obszarze sprawiedliwości rozdzielczej. Subsydiarność zakłada, że każdy szczebel władzy powinien realizować tylko te zadania, które w sposób efektywny nie mogą być realizowane przez władze niższe lub inne instytucje społeczne. Ostatnim z fundamentów KNS jest solidarność. Idea ta stanowi ważną część chrześcijańskiego przesłania, gdyż związana jest z przykazaniem miłości bliźniego. Początkowo rozumiano ją przede wszystkim jako cnotę, później interpretacja jej ewoluowała w kierunku rozumienia jako zasady życia społecznego (Góra-Szopiński, 2007, s. 400).

Symboliczny początek nowożytnej formy nauki społecznej Kościoła łączony jest z encykliką „Rerum novarum” ogłoszoną przez papieża Leona XIII w 1891 roku. W związku z tym najważniejsze dokonania KNS przypadają na wiek XX. W opracowaniu dotyczącym ustrojowej wizji państwa w nauczaniu społecznym Kościoła katolickiego Dariusz Góra-Szopiński zaproponował podział XX-wiecznej KNS na trzy okresy rozwojowe. Odpowiadają one zmianom w zewnętrznym otoczeniu Kościoła. Przypomnienie ich jest ważne ze względu na fakt, że nauka społeczna papieża Benedykt XVI stanowi egzemplifikację trzeciego, czyli ostatniego okresu rozwoju KNS w wieku XX. Pierwszy etap zamyka się w latach 1900-1940. KNS tego okresu charakteryzuje się krytycznym nastawieniem wobec rozwijających się totalitaryzmów, ale również projektów demokratycznych. Na jej gruncie wypracowany zostaje także własny konstruktywistyczny program polityczny. Drugi etap to lata 1940-1980. W tym okresie ze sceny politycznej zniknęły nazizm i faszyzm, a ruchy prawicowe pogrążyły się 
w kryzysie. Atrakcyjność w dużym stopniu utraciło także autorytarne centrum. Można zaś przyjąć, że najsilniejszy wpływ na życie społeczne miały doktryny szeroko pojętej lewicy. KNS tego czasu otwiera się szerzej na świat, ewoluując w kierunku politycznej lewicy. Ostatni, trzeci etap rozpoczął się w latach 80. dwudziestego wieku i można przyjąć, że trwa do dziś. Rozpoczął się on wraz z końcem dwubiegunowego porządku światowego oraz postępującą globalizacją liberalnego modelu ustrojowego. Nowy status quo wspierany jest przez nowe postacie doktryn konserwatywnych oraz socjaldemokratycznych ewoluujących w kierunku socjalliberalnych. KNS tego czasu nie popiera ruchów autorytarnych i nacjonalistycznych. Można zaś przyjąć, że usiłowała ona tworzyć intelektualne podstawy dla akceptacji dominującego programu liberalnego (Góra-Szopiński, 2007, s. 393-397).

Odnosząc się do zaprezentowanej periodyzacji rozwoju KNS, zauważyć należy, że obserwowalne są już zjawiska, które pozwalają na przypuszczenie, że etap rozwojowy KNS rozpoczęty w latach 80 . dwudziestego wieku zmierza ku swemu końcowi lub już miał on miejsce. Wiązać to należy z przekształceniami ładu globalnego bogato opisywanymi w literaturze politologicznej. Funkcjonuje opinia, że wykrystalizowany po zakończeniu zimnej wojny ład światowy przekształca się w ład wielobiegunowy. Obecna zaś sytuacja charakteryzuje się tym, że stare reguły systemowe już nie funkcjonują w sposób wydajny, nowe zaś jeszcze nie zostały ustanowione (Cimek, 2016, s. 8). Immanuel Wallerstein określa taką sytuację zapożyczonym z nauk przyrodniczych terminem bifurkacja. Bifurkację rozumieć należy jako sytuację, w której elementarne równania jakiegoś systemu dają się rozwiązać na dwa odmienne sposoby (Wallerstein, 2007, s. 111).

Kościół jako instytucja funkcjonująca w ramach systemu globalnego zapewne będzie musiał uwzględniać w swej doktrynie społecznej tego systemu przemiany. Jeśli tego nie zrobi, trudno będzie mu realizować swoją misję ewangelizacyjną. Kościół rozumiany jako instytucja musi trwać w czasie i mieć możliwości oddziaływania na rzeczywistość społeczną. Dlatego KNS zmuszona jest umieć twórczo odpowiadać na nowe społeczne problemy, które niesie ze sobą globalizacja. Niewątpliwie, pośrednio z sytuacji zdawał sobie sprawę papież Benedykt XVI. Papież Senior w ostatnim udzielonym przez siebie wywiadzie rzece pt. "Ostatnie rozmowy” sam siebie nazwał mianem Papieża „pomiędzy czasami”. Poproszony przez interlokutora Petera Seewalda o sprecyzowanie, co ma na myśli, Ojciec Święty podkreślił, że uważa, iż nie należy on już do „starego świata”, nowy jednak ciągle nie istnieje (Benedykt XVI, 2016, s. 270). 


\section{BENEDYKT XVI - PAPIEŻ ZACHODNIEJ DEMOKRACJI}

Władza polityczna, określana także jako władza państwowa, stanowi jedno z centralnych pojęć nauki o polityce. Według klasycznej definicji Maxa Webera władza to szansa przeprowadzenia swej woli nawet w sytuacji oporu, $w$ ramach pewnego stosunku społecznego (Weber, 2002, s. 39). Sprawowanie władzy w praktyce może polegać na wywieraniu wpływu, przekonywaniu, manipulacji, a w skrajnych przypadkach wręcz na przemocy (Von Beyme, 2007, s. 170). Konieczność istnienia stosunków władczych stanowi bezpośrednią konsekwencję faktu występowania sprzeczności pomiędzy interesami jednostek i grup społecznych. Obok zjawiska władzy wyróżnia się także wspomniany wcześniej fenomen politycznego wpływu. Definiowany jest on jako zdolność skutecznego nakłaniania do postępowania zgodnego z nasza wolą lub zdolność spowodowania zmiany w sposobie myślenia, dążeniach i postępowaniu (Gulczyński, 2007, s. 57 i 60).

Fenomen władzy politycznej stanowi również jeden z najważniejszych przedmiotów zainteresowania nauki społecznej Kościoła. Źródło pierwotnych wskazań odnośnie tego, jaki winien być stosunek chrześcijan do władzy, twórcy Kościoła upatrują - rzecz oczywista - w Biblii. Autorzy wydanego w 2005 roku Kompendium Nauki Społecznej Kościoła wskazują, że biblijne przesłanie stanowi ustawiczną inspirację dla myśli chrześcijańskiej na temat władzy politycznej. Pismo Święte, ich zdaniem, przede wszystkim przypomina, że władza ma swe źródło w Bogu i stanowi część stworzonego przez niego porządku (Kompendium Nauki Społecznej Kościoła, 2005, s. 774).

$\mathrm{Na}$ kartach Biblii czytamy, że Jezus odrzuca władzę tych, którzy ciemiężą narody. Nie podważał on jednak w sposób bezpośredni legitymacji ówczesnych władz politycznych (Mk 10, 42; Łk 22, 25)². Co więcej, w dyskusji na temat płacenia podatków cezarowi podkreślił on, że jest to konieczność, przy jednoczesnym zastrzeżeniu, że władza nie powinna ingerować w sferę religijną (Mk 12,13-17; Mt 22, 15-22; Łk 20, 20-26).

Obok spisanych w Ewangeliach słów i czynów Jezusa wyraźne biblijne odniesienie do zagadnienia władzy politycznej odnaleźć można w refleksji św. Pawła. Apostoł doprecyzował zasady stosunku do władzy oraz obowiązków wobec niej. Stał on na stanowisku, że chrześcijanin powinien podporządkować się władzy, ale nie w sposób bierny. Warunki brzegowe podporządkowania powinno wyznaczać

2 Wszystkie przypisy dotyczące Biblii odwołują się do: Pismo Święte Starego i Nowego Testamentu. Biblia Tysiaclecia, 2012. 
sumienie, które pozwala dostrzec ustanowiony przez Boga porządek (Rz 13,1-7). Ponadto zalecana przez św. Pawła modlitwa za rządzących wskazuje minimum, jakie władza polityczna powinna zagwarantować wiernym (1 Tm 2,1-2).

Stosunek KNS do władzy politycznej pozostaje wyraźnie związany z definicją wspólnoty politycznej. Kościół naucza, że osoba ludzka jest istotą społeczną i polityczną. Przypomina on także, że wspólnota polityczna istnieje dlatego, że spełnia określone zadanie. Celem istnienia wspólnoty politycznej jest stworzenie warunków do możliwie najpełniejszego wzrostu każdego z jej członków. Zdaniem Kościoła wspólnota polityczna swój najpełniejszy wymiar wyraża w narodzie (Kompendium Nauki Społecznej, 2005, s. 779-780).

W bezpośrednim odniesieniu do władzy politycznej KNS podkreśla, że Kościół stoi na gruncie konieczności obrony modelu opartego na społecznej naturze osób. Władza polityczna potrzebna jest więc dla realizacji powierzonych jej zadań. Dlatego powinna ona być częścią społeczności cywilnej. Zadaniem jej jest porządkowanie życia wspólnoty i ukierunkowywanie go na realizację dobra wspólnego. Władza nie może jednak zastępować wolnego działania jednostek. Podmiotem jej jest naród, który jest suwerenny w swoim całokształcie. Naród ten, jak i poszczególna jednostka, mogą też wypowiedzieć posłuszeństwo władzy, jeśli ta postępuje niezgodnie z zasadami moralnego porządku, podstawowymi prawami osób lub wskazaniami Ewangelii (Kompendium Nauki Społecznej, 2005, s. $799-803$ i 820 ).

W kontekście współczesnej rzeczywistości politycznej ważny jest także stosunek KNS do demokracji. Zdaniem Kościoła „prawdziwa demokracja” nie ma jedynie formalnego charakteru, ale jest rezultatem wartości, które procedury demokratyczne inspirują. Jeśli chodzi o zagrożenie dla współczesnej demokracji, to KNS upatruje je przede wszystkim w relatywizmie etycznym prowadzącym do negacji obiektywnych kryteriów określających hierarchię wartości w życiu politycznym (Kompendium Nauki Społecznej, 2005, s. 838).

Powyżej zarysowane zostało doktrynalne tło, na jakim Benedykt XVI musiał tworzyć swoje koncepcje związane $\mathrm{z}$ władzą polityczną. $\mathrm{Z}$ punktu widzenia głowy współczesnego Kościoła katolickiego kluczowym problemem zdaje się być to, jak połączyć postulat boskiego pochodzenia władzy z powszechnością faktu (przynajmniej w kręgu kultury zachodniej), że władza musi posiadać jakąś formę demokratycznej legitymizacji. Problem ten rozwiązany został na gruncie personalizmu chrześcijańskiego, który wypracował koncepcję, zakładającą, że demokracja może działać prawidłowo jedynie wtedy, gdy stoją za nią metapolityczne chrześcijańskie wartości. Taka interpretacja znosi problem ewentualnego 
braku boskiej legitymizacji, gdyż politycy walczący o władzę w ramach opartego o chrześcijańskie wartości systemu demokratycznego sami muszą je wyznawać. W innym wypadku „prawdziwa” demokracja musi niechybnie upaść.

Analizując nauczanie Benedykta XVI odnośnie do władzy politycznej, podkreślić należy, że Papież rozwijał je, trzymając się ścisłych założeń, o których wielokrotnie w swych wypowiedziach przypominał. Pierwsze z nich dotyczy tego, że Jezus nie był mesjaszem politycznym. Jego celem było przede wszystkim zbawienie pogrążonej w grzechu ludzkości. Papież podkreślał, że błędem jest utożsamianie posłannictwa Jezusa $\mathrm{z}$ reformami politycznymi nawet $\mathrm{w}$ sytuacji, kiedy mówi on o Królestwie Bożym (Mt 5, 1-12). Drugie założenie związane było z postulowanym stosunkiem wiernych do instytucji państwa. W duchu tradycji KNS Benedykt XVI przypominał o wyrażonej przez Jezusa akceptacji dla płacenia podatków (Mt 22,21). Ostatnie dotyczy tego, że chrześcijanin nie ma prawa głosić Ewangelii przy użyciu przemocy. Społeczną aktywność chrześcijan, zdaniem Papieża, charakteryzować powinna miłość i posłuszeństwo (Benedykt XVI, 2007a; Benedykt XVI, 2009a; Ratzinger, 2004a, s. 56-57).

Pierwszy, dotyczący zagadnienia władzy politycznej problem, jaki podnosił Benedykt XVI, związany jest z jej pochodzeniem i kwestią posłuszeństwa władzy. W zgodzie z KNS Papież podkreślał, że jedynym źródłem władzy jest Bóg. W uzasadnieniu odwoływał się on do fragmentu Listu do Rzymian autorstwa św. Pawła. Apostoł Narodów mówi w nim wprost, że władza ma charakter hierarchiczny i nie istnieje żadna władza, która nie miałaby boskiego źródła (Rz 13, 1-7). Benedykt XVI, odnosząc się do słów św. Pawła, przypomina, że w ten boski porządek wkomponowany jest człowiek, który w stosunku do innych stworzeń posiada szczególną godność. Jeszcze jako kardynał Ratzinger podkreślał, że w uznaniu autorytetu władzy przejawia się boski porządek, w którym człowiek jako osoba może partycypować (Ratzinger, 2004a, s. 53). Niemniej brak podporządkowania władzy musi nieść ze sobą konsekwencje. W takim wypadku, jak wskazuje Benedykt XVI, interweniować powinny instytucje państwa, które ze względu na posiadanie bożej legitymacji mają prawo do zwalczania zła w świecie polityki. W refleksji dotyczącej moralnego charakteru władzy Benedykt XVI, jako Papież, utrzymał swój artykułowany wcześniej pogląd (odwołujący się do św. Pawła), że władza ma przede wszystkim charakter moralny, który dotyczy rządzących oraz rządzonych (Ratzinger, 1999, s. 48-51).

Obok zagadnienia pochodzenia i posłuszeństwa władzy Benedykt XVI rozważał również, w jaki sposób powinna być ona sprawowana. Odwołuje się on do sformułowanego na gruncie KNS postulatu komplementarności. Jako 
doktrynalne uzasadnienie tej myśli przywołać można encyklikę Jana XXIII „Pacem in terris” (Jan XXIII, 2007). Papież wskazuje w niej m.in., że głównym obowiązkiem państwa jest układanie i regulowanie stosunków pomiędzy członkami społeczeństwa tak, aby prawa wszystkich uczestników życia społecznego były poszanowane. $\mathrm{W}$ tym duchu, nawiązując do doświadczeń egzystencjalnych człowieka, rozwija swą refleksję na temat wykonywania władzy państwowej Benedykt XVI (Szulist, 2016, s. 365).

Liczne wskazania na temat polityki i władzy Benedykt XVI wygłosił w kontekście refleksji o charakterze antropocentrycznym. Następca Jana Pawła II w swych wystąpieniach podkreślał, że naczelnym postulatem władzy państwowej powinna być zawsze troska o dobro osoby ludzkiej. Przypominał on, że społeczeństwo powinno być zorganizowane tak, aby ludzie mogli żyć godnie. W swej refleksji na temat godności Papież nie lekceważył drobnych kwestii materialnych. Obok godnego życia niemniej ważnym społecznym minimum były dla Papieża warunki umożliwiające przetrwanie rodziny. Wychodząc od tych postulatów, Benedykt XVI apelował do ludzi sprawujących władzę oraz tych, którzy uczestniczą w procesie przekazywania wartości, aby mieli odwagę mówić „prawdę o człowieku”, czyli przypominać o istocie człowieczeństwa. Zewnętrzne, utrudniające przekazywanie owej „prawdy”, ograniczenia Papież widział w takich zjawiskach, jak: dążenie do władzy i zysku za wszelką cenę, narkomania, nieuporządkowane związki uczuciowe, zamieszanie w kwestii małżeństwa oraz nieuznawanie ludzkiej istoty na wszystkich etapach jej życia (Benedykt XVI, 2009b).

Niezależnie od potępiania dla zjawisk, które w jego ocenie mają charakter szkodliwy dla człowieka, Benedykt XVI w żadnym wypadku nie postulował dystansowania się katolików od świata polityki. Uważał, że wierni (szczególnie w krajach, gdzie stanowią oni większość) powinni angażować się w życie spoleczne i rozwijać relacje z instytucją państwa. Podkreślał on, że w relacji pomiędzy życiem kościelnym a społeczno-politycznym znów na plan pierwszy wysuwa się fenomen osoby jako podmiotu najważniejszego. Benedykt XVI podkreślał, że solidarność realizowana może być jedynie wtedy, gdy żywotne siły społeczne będą angażować się na rzecz przyszłości, dającej pokój i nadzieję wszystkim ludziom (Benedykt XVI, 2007b).

Obok zwykłych obywateli zaangażowanych na rzecz życia społecznego osobną refleksję Benedykt XVI poświęcał ludziom politykę uprawiającym zawodowo. Reprezentował on stanowisko akcentujące, że głównym zadaniem polityków jest działanie na rzecz dobra wspólnego. Przypominał on, że ludzie 
jedynie w ramach wspólnoty mogą je osiągnąć (Benedykt XVI, 2010a). W ślad za KNS Benedykt XVI przypominał także, że politycy sprawujący funkcje państwowe robić muszą to $\mathrm{w}$ duchu sankcji moralnej oraz szukać inspiracji w bożych nakazach. Zadaniem polityka jest także budowanie „prawdziwych wspólnot”, czyli takich, które w sposób bezgraniczny będą podporządkowane osobie (Konstytucja duszpasterska o Kościele w świecie współczesnym, 2005). Ponadto Benedykt XVI zwracał uwagę, że w osobie polityka obecna jest jednocześnie tożsamość Chrystusowa i narodowa. Odpowiedzialność rządzących wobec narodu dotyczy zaś dwóch kwestii. Po pierwsze troski o przestrzeganie praw człowieka w ramach społeczności narodowej; po drugie obrony i rozwoju tradycji narodowej. Problemu pielęgnowania wymienionych wartości Papież nie zostawia jednak jedynie w rękach państw narodowych. Podkreśla, że na zasadach określonych w prawie międzynarodowym mogą one liczyć na pomoc ze strony organizacji międzynarodowych oraz innych państw (Benedykt XVI, 2008a).

Obok zagadnienia prawdy o człowieku i wizji polityki na niej opartej, w antropocentrycznej refleksji Benedykta XVI pojawiło się również tak ważne z punktu widzenia różnych filozofii i doktryn politycznych pojęcie, jak „wolność”. Ojciec Święty stał na stanowisku, że wolność to z punktu widzenia rozwoju człowieka we wspólnocie politycznej kwestia fundamentalna. Definiował ją jako podążanie drogą prawdy, w zgodzie z sumieniem i ze świadomością, że po śmierci nasze uczynki zostaną ocenione. Papież podkreślał także, że droga dobrego postępowania nie jest łatwa, ale wiąże się z wieloma wymaganiami i trudami (Benedykt XVI, 2008a).

Krytycznie odnosząc się do poglądów Benedykta XVI, należy zwrócić uwagę, że w dużym stopniu stanowią one powtórzenie klasycznych tez KNS. Nowym elementem wprowadzonym przez następcę Jana Pawła II jest przede wszystkim rozwinięcie rozumienia zasady solidarności jako „solidarności globalnej”. Zdaniem Benedykta XVI solidarność globalna winna być realizowana przez rządzących poprzez działania na rzecz likwidacji ubóstwa stanowiącego konsekwencję postępujących procesów globalizacyjnych (Nowacka, 2009, s. 27).

Osobnym, wspominanym pokrótce wcześniej, a wartym szerszego omówienia problemem jest stosunek papieża Benedykta XVI do dominującego współcześnie, w kręgu kultury zachodniej, systemu politycznego, jakim jest demokracja. Ideą nieodłącznie związaną z demokracją jest różnie definiowana „wolność”. Kościół uczy, że niezależnie od starań poszczególnych jednostek, człowiek nie będzie w stanie rozwijać siebie w duchu wolności, jeśli władze polityczne nie będą go w tym wspierać. W tym kontekście Papież wygłosił jedną z najciekawszych swych 
wypowiedzi, w której odwołał się do konkretnego modelu współpracy pomiędzy władzą polityczną a obywatelami. W trakcie swojej wizyty w Angoli w roku 2009, mówiąc o przemianach społeczności tego kraju, Ojciec Święty zwracał uwagę, że powinna ona opierać się na zasadach współczesnych demokracji obywatelskich. System ten, zdaniem Papieża, bazuje na: poszanowaniu i umacnianiu praw człowieka, przejrzystym sprawowaniu rządów, niezawisłym sądownictwie, wolności w sferze przekazu społecznego, uczciwej administracji publicznej, sieci właściwie działających szkół i szpitali oraz woli położenia kresu korupcji (Benedykt XVI, 2009c).

Przytoczona powyżej opinia Papieża wyraźnie wskazuje, że w systemie demokratycznym, zorganizowanym wedle tradycji zachodniej, widział on optymalną polityczną propozycję dla państw współczesnych. W innej wypowiedzi zauważył on także, że współczesny system polityczny, w ramach którego wolność przyjmuje najbardziej wyrazistą formę, to właśnie demokracja (Benedykt XVI, 2009d, s. 126-127).W jego interpretacji elementami systemu demokratycznego winno być odniesienie do Boga oraz nienaruszalność dóbr natury osobowej. Gwarantem zachowania tych elementów jest kultywowanie zasady sprawiedliwości i dobra wspólnego. Papież podkreślał, że umożliwiają one jednostkowy rozwój człowieka oraz chronią wspólnotę, stanowiąc podstawę solidarnej odpowiedzialności za nią, niezależną od statusu społecznego. W refleksji Benedykta XVI dotyczącej demokracji jej wymiar przedmiotowy (rozstrzygnięcia polityczne), jak i formalny (procedury demokratyczne), wzajemnie się warunkują w kontekście jądra, jakim jest byt osobowy. W myśli Benedykta XVI odnajdujemy ponadto postulat koegzystencji substancjalnego oraz proceduralnego pojęcia demokracji. Zadaniem rządzących jest wypracowanie takiego konsensusu, który zagwarantuje uszanowanie człowieka jako osoby. W opinii Ojca Świętego odejście od prymatu człowieka poprzez zakwestionowanie jego nienaruszalnego statusu w życiu społecznym prowadzi do powstania demokracji pozornej, w istocie jedynie proceduralnej. Sytuacja taka prowadzi do kryzysu państwa. Ojciec Święty mówi o tym następującym słowami: „(...) proszę, abyście pracowali nad osiągnięciem większego konsensusu w kwestii ogółu wspólnie podzielanych zasad. W przeciwnym razie istnieje niebezpieczeństwo, że nawoływanie do demokracji pozostanie jedynie formalnością proceduralną, która utrwala różnice i sprawia, że problemy stają się jeszcze poważniejsze”. (Benedykt XVI, 2006a).

Narzędziem, które w ocenie Benedykta XVI może pomóc ochronić społeczeństwo przed wypaczeniem demokracji, jest akt prawny konstytucji. Winien on regulować funkcjonowanie mechanizmów państwowych, określać pozycję 
obywatela w strukturach władzy oraz służyć budowie jedności społecznej. Dzięki ustawie zasadniczej łatwiejsza jest ochrona podmiotowości jednostki. Papież zaznacza, że w zapisach samego aktu muszą znaleźć się wskazania, które ograniczą zakres ingerencji państwa w życie człowieka, aby ten mógł zachować wolności, które są warunkiem godności (Benedykt XVI, 2011a).

Konstytucja sama jednak nie wystarczy, aby ochronić człowieka. Niezbędne jest, aby była ona oparta na wartościach, z których najważniejszą jest Bóg. W odwołaniu do nauczania Benedykta XVI można sformułować wniosek, iż wspólnoty polityczne wręcz domagają się istnienia Boga (Ratzinger, 2004a, s. 52-55). Aksjomat ten pozostaje zaś nierozerwalnie związany z zagadnieniem wolności religijnej. W ocenie Benedykta XVI wolność religijna jest pierwszym z praw człowieka. Ponadto uważa on, że realizacja prawa do wolności religijnej i wolności sumienia stanowi dowód chrześcijańskiego wkładu w życie społeczne. Mówi on, że:„(...) krzewienie prawdziwej wolności religijnej i wolności sumienia, będącej jednym z podstawowych praw człowieka, którego winno przestrzegać zawsze każde państwo". (Benedykt XVI, 2010b). Benedykt XVI, odwołując się do Alexisa de Tocqueville’a, podkreśla, że wolność religijna sprzyja kształtowaniu się demokracji. Łączność wolności religijnej i demokracji, zdaniem Papieża, warunkują dwa elementy. Pierwszy związany jest z tym, że religijność stanowi cechę naturalną człowieka jako osoby; drugi wynika z tego, że w dobie masowych ruchów migracyjnych pokojowe formy współżycia przedstawicieli różnych religii są warunkiem przetrwania wspólnot politycznych w ogóle. Demokracja w tym zakresie tworzy wykluczające przemoc warunki rozwiązywania konfliktów (Benedykt XVI, 2008b).

Innym warunkiem funkcjonowania demokracji - zdaniem Benedykta XVI - jest obecność i oddziaływanie sumienia. Na bazie KNS naucza on, że z perspektywy moralności chrześcijańskiej człowiek jest w stanie oceniać sytuację społeczno-polityczną. Dlatego, zdaniem Benedykta XVI, demokracja zdolna jest do funkcjonowania tylko wówczas, gdy działa sumienie (Benedykt XVI, 2008b). Warto nadmienić, że ten konkretny temat Ojciec Święty poruszył w trakcie pobytu w Polsce w roku 2007. Podkreślił on przy tym, że historia polskiej wolności jest dobrym przykładem wzajemnego uzupełniania się sumienia i demokracji.

Analizując nauczanie Benedykta XVI na temat demokracji, można sformułować opinię, że niektóre jego wypowiedzi mają charakter mocno waloryzujący ten system polityczny. Ojciec Święty zauważa m.in., że jedynie demokratyczna forma rządów stanowi system polityczny, który jest w stanie zagwarantować 
równość wobec prawa. Dlatego też obywatele oraz społeczność międzynarodowa powinny działać na rzecz demokratyzacji (Benedykt XVI, 2006b). Żeby system ten mógł się w przyszłości rozwijać, konieczne jest spełnienie takiego warunku jak budowa instytucji, które będzie cechowała odpowiedzialność, wiarygodność oraz powszechnie uznany autorytet. Podmioty te będą sprawnie działać oraz kształtować aktywnych społecznie obywateli (Benedykt XVI, 2011b). Drugi wskazany przez Benedykta XVI warunek dotyczy rozwoju demokracji. Zdaniem Papieża rozwijać się ona może tylko w sytuacji, gdy istnieje stan sprawiedliwości społecznej, czyli wtedy, gdy całość społeczeństwa jest w posiadaniu optymalnej ilości dóbr egzystencjalnych oraz nie istnieje zjawisko wyzysku grup zmarginalizowanych (Benedykt XVI, 2011d).

\section{PODSUMOWANIE}

Odnosząc się do nauczania Benedykta XVI w zakresie władzy politycznej, należy zauważyć, że w sposób wyraźny i jednoznaczny odrzuca on interpretację postaci Jezusa jako fenomenu stricte politycznego. Myślenie to jest spójne z rozwijaną wcześniej przez Josepha Ratzingera krytyką południowoamerykańskiej teologii wyzwolenia, widzącej w Jezusie wyzwoliciela politycznego. Ówczesny prefekt Kongregacji Nauki Wiary odrzucał taką interpretację, argumentując, że program teologii wyzwolenia zakładał fizyczną walkę ze strukturami bezprawia: wówczas zbawienie nabiera charakteru procesu politycznego opartego na filozofii marksistowskiej (Ratzinger, 2004b, s. 93-94).

Benedykt XVI stoi niewątpliwie na gruncie tradycyjnego dla KNS rozumienia rozdziału Kościoła i władzy politycznej, który zakłada ich odrębną koegzystencję. Jako źródło pierwotne władzy Papież wskazuje jednak na Boga, odrzucając idee legitymizacji wynikającej z kontraktu społecznego. KNS i Benedykt XVI podkreślają, że obywatele w wyniku aktu demokratycznego przyznają politykom uprawnienia i nakładają na nich zadania. Sama władza pochodzi jednak niezmiennie od Boga. Umowa społeczna jest tutaj elementem pochodnym.

Benedykt XVI w swym nauczaniu społecznym często odwołuje się do stanowiącej jeden z filarów KNS, zakorzenionej w personalizmie chrześcijańskim, idei antropocentrycznej. W oparciu o nią wysuwa on postulaty o niewątpliwym socjalnym zabarwieniu, które mówią o konieczności zapewnienia przez państwo godnych warunków materialnych niezbędnych do życia ludzi. Odpowiedzialnym 
za realizację tych idei jest jednak państwo. Kościół może być tu jedynie recenzentem określonych strategii politycznych.

Niewątpliwie jednak, w sposób najszerszy swoje nauczanie odnoszące się do władzy politycznej papież Benedykt XVI wykładał w kontekście zagadnienia demokracji. Zauważyć należy, że optymalny wariant systemu demokratycznego postrzegał on w modelu, który ukształtował się po II wojnie światowej w kręgu kultury zachodniej. Demokracja ta podstawę swą znajdować powinna w opartych na przesłaniu chrześcijańskim wartościach, na których ufundowana będzie konstytucja. System ten gwarantować powinien poszanowanie praw człowieka, transparentny system rządów, istnienie niezawisłego sądownictwa oraz działanie instytucji wspierających człowieka. Żeby lepiej zrozumieć poglądy Benedykta XVI na demokrację, warto wrócić do tocznej przez niego w roku 2004 debaty $\mathrm{z}$ Jürgenem Habermasem. W jej ramach wyraźnie zarysowany został, tak ważny z punktu widzenia dyskusji na temat współczesności, rozdzierający Europę podział na kulturę wiary chrześcijańskiej i świeckiej racjonalności³. Rozmowa między filozofami wykazała, że najistotniejsza sprzeczność między dwoma typami europejskiej racjonalności (chrześcijańskim i świeckim) nie leży w interpretacji zasad, wedle których powinno funkcjonować współczesne demokratyczne społeczeństwo, ale w definicji ich źródeł. Habermas opowiadał się za wypracowywaniem reguł współżycia społecznego na drodze dyskusji. J. Ratzinger uważał zaś, że zasad nie trzeba tworzyć, tylko ponownie odnaleźć, gdyż obecne są one w chrześcijańskich korzeniach Europy (Iwanicki, 2010, s. 185-190; A. Kobyliński, 2007, s. 331-334; Korab-Karpowicz, 2011, s. 175-190; Obirek, 2014, s. 13-25; Teinert, 2006, s. 151-168; Wigura, 2012, s. 146-167).

W odniesieniu do zaproponowanej na początku periodyzacji rozwoju KNS można stwierdzić, że Benedykt XVI i jego nauczanie w pełni wpisują się w jej ostatni, rozpoczęty po zakończeniu zimnej wojny, etap. Papież wyraźnie deklarował swe poparcie dla systemów demokratycznych, dystansując się od innego typu rozwiązań politycznych dotyczących zarządzania państwem. Niemniej należy także zauważyć, że w okresie pontyfikatu Benedykta XVI (2005-2013) zaczęły uwidaczniać się procesy polityczne (np. obiektywne słabnięcie Stanów Zjednoczonych, wzrost potęgi Chin, kryzys zachodniego systemu gospodarczego i poli-

3 Przebieg debaty opublikowany został w wydanej w języku niemieckim w roku 2005 książce (Habermas, Ratzinger, 2005). W roku 2006 książka została wydana w języku angielskim (Habermas, J. Ratzinger, 2006). Publikacja nie została przetłumaczona na język polski (stan na 2017 rok). Niemniej w Polsce wystąpienia z debaty zaprezentowano m.in. w „Tygodniku Powszechnym” nr 18/2005, oraz w tygodniku „Europa” nr 1/2004. 
tycznego czy wielkie ruchy migracyjne w Europie), które pozwalają przypuszczać, że KNS w odpowiedzi na te wyzwania będzie musiała dokonać reinterpretacji i rozwinięć niektórych swych elementów. Prawdopodobnie wyraźniej widoczne będzie to w nauczaniu społecznym następców Benedykta XVI. Przedsmak tego zjawiska widoczny jest już w wystąpieniach papieża Franciszka.

\section{BIBLIOGRAFIA:}

Benedykt XVI. (2007a). List Ojca Świętego Benedykta XVI do Biskupów, do Kapłanów, do Osób Konsekrowanych oraz do Wiernych Świeckich Kościoła katolickiego w Chińskiej Republice Ludowej. L'Osservatore Romano, 9. Pobrane z: https://opoka. org.pl/biblioteka/W/WP/benedykt_xvi/listy/chiny_27052007.html.

Benedykt XVI. (2008a). Prawa człowieka są wyrazem sprawiedliwości. L’Osservatore Romano, 5. Pobrane z: https://opoka.org.pl/biblioteka/W/WP/benedykt_xvi/ przemowienia/usa_onz_18042008.html.

Benedykt XVI. (2009a). Królestwo Jezusa przechodzi przez krzyż i jest uniwersalne. L'Osservatore Romano, 6. Pobrane z: https://www.deon.pl/religia/serwis-papieski/ benedykt-xvi/homilie-benedyktaxvi/art,141,krolestwo-jezusa-przechodzi-przezkrzyz-i-jest-uniwersalne.html.

Benedykt XVI. (2016). Ostatnie rozmowy. Kraków.

Benedykt XVI. (2006a). Dla dobra człowieka i całego społeczeństwa. L'Osservatore Romano, Pobrane z: https://opoka.org.pl/biblioteka/W/WP/benedykt_xvi/przemowienia/acli_27012006.html.

Benedykt XVI. (2007b). Katolicy winni w sposób szczególny służyć wspólnemu dobru narodu. L'Osservatore Romano, 7/8. Pobrane z: https://opoka.org.pl/biblioteka/W/ WP/benedykt_xvi/przemowienia/brazylia_powitalne_09052007.html.

Benedykt XVI. (2008b). Brońmy razem życia i wolności religijnej na świecie, L'Osservatore Romano, 5. Pobrane z: https://opoka.org.pl/biblioteka/W/WP/benedykt_xvi/ przemowienia/usa_religie_17042008.html.

Benedykt XVI. (2009c). Afrykanie powinni być pierwszymi twórcami swego rozwoju.

L'Osservatore Romano, 5. Pobrane z: https://opoka.org.pl/biblioteka/W/WP/benedykt_xvi/przemowienia/afryka_angola2_20032009.html.

Benedykt XVI. (2009d). Kościót. Wspólnota w drodze. Kielce.

Benedykt XVI. (2009b). Pomagajcie ludziom budować lepsze życie. L'Osservatore Romano, 6. Pobrane z: https://opoka.org.pl/biblioteka/W/WP/benedykt_xvi/ przemowienia/akademiapar_10022007.html.

Benedykt XVI. (2010a). Osoba ludzka i dobro wspólne w centrum zarządzania sprawami publicznymi. L'Osservatore Romano, 3/4. Pobrane z: https://opoka.org.pl/ biblioteka/W/WP/benedykt_xvi/przemowienia/lacjum_14012010.html.

Benedykt XVI. (2010b). Pokój jest warunkiem godnego życia. L'Osservatore Romano, 12. Pobrane z: https://opoka.org.pl/biblioteka/W/WP/benedykt_xvi/homilie/ bliskiwschod_24102010.html. 
Benedykt XVI. (2011a), Serce rozumne. Refleksje na temat podstaw prawa, L'Osservatore Romano, 10-11. Pobrane z: https://opoka.org.pl/biblioteka/W/WP/benedykt_xvi/ przemowienia/niemcy2011_bundestag_22092011.html.

Benedykt XVI. (2011c). Jak naprawić demokrację? L'Osservatore Romano, 9-10. Pobrane z https://opoka.org.pl/biblioteka/W/WP/benedykt_xvi/przemowienia/demokracja_19052006.html/.

Benedykt XVI. (2011d). Prawo do wolności religijnej jest ściśle związane z godnością każdego człowieka. L’Osservatore Romano, 7. Pobrane z: https://opoka.org.pl/ biblioteka/W/WP/benedykt_xvi/przemowienia/akademians_29042011.html.

Benedykt XVI. (2011b). W zmieniającym się świecie strzeżcie wielkiego dziedzictwa tej ziemi. L'Osservatore Romano, 6. Pobrane z https://opoka.org.pl/biblioteka/W/WP/ benedykt_xvi/przemowienia/akwilea-triveneto_07052011.html.

Cimek, G. (2016). Podstawowe problemy geopolityki i globalizacji. Gdańsk: AMW.

Góra-Szopiński, D. (2007). Złoty środek. Kościół wobec współczesnych wizji państwa. Toruń: Wydawnictwo Adam Marszałek.

Góra-Szopiński, D. (2010). Katolicka nauka społeczna jako wyzwanie dla politologii. Athenaeum. Polskie Studia Politologiczne, 24.

Gulczyński, M. (2007). Nauka o polityce. Warszawa: AlmaMer.

Habermas, J., Ratzinger, J. (2005). Dialektik der Säkularisierung. Über Vernunft und Religion. Freiburg.

Habermas, J., Ratzinger, J. (2006). The Dialectics of Secularization. On Reason and Religion. San Francisco.

Iwanicki, J. (2010). Spór i dialog Jürgena Habermasa z Josephem Ratzingerem o miejsce religii w życiu publicznym Europy. Przegląd Religioznawczy, 4.

Jan XXIII. (2017). Encyklika Pacem in terries. Pobrane z: http://www.opoka.org.pl/ biblioteka/W/WP/jan_xxiii/encykliki/pacem_in_terris_11041963.html.

Keller, J. (1989). Katolicka Doktryna Społeczna. Warszawa.

Kobyliński, A. (2007). Etica, religione e stato liberale. Joseph Ratzinger - Jurgen Habermas [recenzja]. Studia Płockie, 35.

Kompendium Nauki Społecznej Kościoła. (2005). Kielce.

Konstytucja duszpasterska o Kościele w świecie współczesnym. (2005). Poznań.

Korab-Karpowicz, W.J. (2011). Religia, rozum i to, co zostało utracone: dyskusja z Jürgenem Habermasem. W: Religa a prawo i państwo (Wrocławskie Studia Erazmiańskie: zeszyt naukowy studentów, doktorantów i pracowników Uniwersytetu Wrocławskiego). Nowacka, E.J. (2009). Wprowadzenie do doktryny społecznej Benedykta XVI. Wrocław. Obirek, S. (2014). O sekularyzacji dialektycznie. Case study Habermas-Ratzinger, Humaniora. Czasopismo Internetowe, 2.

Pismo Święte Starego i Nowego Testamentu. Biblia Tysiąclecia. (2012). Poznań.

Possenti, V. (2000). Katolicka nauka społeczna wobec dziedzictwa oświecenia. Kraków: WAM. Ratzinger, J. (2004a). Europa. Jej podwaliny dziś i jutro. Kielce: Jedność.

Ratzinger, J. (1999). Urząd nauczycielski Kościoła - wiara - moralność. W: Podstawy moralności chrześcijańskiej. Poznań: W drodze. 
Ratzinger, J. (2004b). Wiara - prawda - tolerancja. Chrześcijaństwo a religie świata. Kielce: Jedność.

Ratzinger, J., Benedykt XVI. (2011). Jezus z Nazaretu. Część I. Od chrztu w Jordanie do Przemienienia, Kraków: Wydawnictwo M.

Szulist, J. (2016). Teologia państwa w pismach Josepha Ratzingera (Benedykta XVI). Toruń.

Teinert, Z. (2006), Habermas i Ratzinger: wiara i wiedza w dobie sekularyzacji. Poznańskie Studia Teologiczne, 20.

Von Beyme, K. (2007). Współczesne teorie polityczne. Warszawa: Wydawnictwo Naukowe Scholar.

Wallerstein, I. (2007). Analiza systemów-światów. Wprowadzenie, Warszawa: Wydawnictwo Akademickie Dialog.

Weber, M. (2002). Gospodarka i społeczeństwo. Warszawa: Wydawnictwo Naukowe PWN.

Wigura, K. (2012). Pokolenie pomocników artylerii. Habermas, Ratzinger, Luhmann i niemieckie spory. Stan Rzeczy, 1(2). 